\title{
Under-ice metabolism in a shallow lake in a cold and arid climate
}

\section{Song, Shuang}

2019-10

Song , S, Li , C , Shi , X , Zhao , S, Tian , W , Li , Z, Bai , Y, Cao , X, Wang , Q, Huotari , J , Tulonen , T , Uusheimo , S , Leppäranta , M , Loehr , J \& Arvola , L 2019 , ' Under-ice metabolism in a shallow lake in a cold and arid climate ', Freshwater Biology , vol. 64 , no. 10 , pp. 1710-1720 . https://doi.org/10.1111/fwb.13363

http://hdl.handle.net/10138/327111

https://doi.org/10.1111/fwb.13363

unspecified

acceptedVersion

Downloaded from Helda, University of Helsinki institutional repository.

This is an electronic reprint of the original article.

This reprint may differ from the original in pagination and typographic detail.

Please cite the original version. 


\section{Freshwater Biology}

\section{Under-ice metabolism in a shallow lake in a cold and arid climate zone}

\begin{tabular}{|c|c|}
\hline Journal: & Freshwater Biology \\
\hline Manuscript ID & FWB-P-Sep-18-0429 \\
\hline Manuscript Type: & Standard Paper \\
\hline Date Submitted by the Author: & 11-Sep-2018 \\
\hline Complete List of Authors: & $\begin{array}{l}\text { Song, Shuang; Inner-Mongolia Agricultural University, Water Conservancy } \\
\text { and Civil Engineering College; University of Helsinki, Lammi Biological } \\
\text { Station } \\
\text { Li, Changyou; Inner-Mongolia Agricultural University, Water Conservancy } \\
\text { and Civil Engineering College } \\
\text { Shi, Xiaohong; Inner-Mongolia Agricultural University } \\
\text { Zhao, Shengnan; Inner-Mongolia Agricultural University, Water } \\
\text { Conservancy and Civil Engineering College } \\
\text { Tian, Weidong; Inner-Mongolia Agricultural University, Water Conservancy } \\
\text { and Civil Engineering College } \\
\text { Li, Zhijun; Dalian University of Technology, State Key Laboratory of Coastal } \\
\text { and Offshore Engineering } \\
\text { Bai, Yila; Bohai University, School of Mathematics and Physics } \\
\text { Cao, Xiaowei; Dalian University of Technology, State Key Laboratory of } \\
\text { Coastal and Offshore Engineering } \\
\text { Wang, Qingkai; Dalian University of Technology, State Key Laboratory of } \\
\text { Coastal and Offshore Engineering } \\
\text { Huotari, Jussi; University of Helsinki, Lammi Biological Station } \\
\text { Tulonen, Tiina; University of Helsinki, Lammi Biological Station } \\
\text { Uusheimo, Sari; University of Helsinki, Lammi Biological Station } \\
\text { Leppäranta, Matti; University of Helsinki } \\
\text { Arvola, Lauri; University of Helsinki, Lammi Biological Station }\end{array}$ \\
\hline Keywords: & $\begin{array}{l}\text { Lakes < Habitat, Ecosystem < Level of Organisation, Wetlands / mires / } \\
\text { bogs / marshes < Habitat, Physical environment < Level of Organisation, } \\
\text { Plankton < Taxonomic Group / Assemblage, Macroalgae < Taxonomic } \\
\text { Group / Assemblage, Primary production < Process / Approach / Methods, } \\
\text { Decomposition < Process / Approach / Methods }\end{array}$ \\
\hline
\end{tabular}




\title{
Under-ice metabolism in a shallow lake in a cold and arid climate zone
}

\author{
Under-ice lake metabolism
}

\author{
Shuang Song ${ }^{\dagger}$, Changyou $\mathrm{Li}^{\dagger}$, Xiaohong Shi ${ }^{\dagger}$, Shengnan Zhao ${ }^{\dagger}$,Weidong Tian ${ }^{\dagger}$, Zhijun $\mathrm{Li}^{\ddagger}$, Yila \\ $\mathrm{Bai}^{\S}$, Xiaowei Cao ${ }^{\ddagger}$, Qingkai Wang ${ }^{\ddagger}$ Jussi Huotari", TiinaTulonen", Sari Uusheimo", Matti \\ Leppäranta ${ }^{\ddagger}$ Lauri Arvola
}

Addresses:

${ }^{\dagger)}$ Water Conservancy and Civil Engineering College, Inner-Mongolia Agricultural University, Hohhot, China

${ }^{\ddagger}$ State Key Laboratory of Coastal and Offshore Engineering, Dalian University of Technology, Dalian, China

${ }^{\S)}$ School of Mathematics and Physics, Bohai University, China

() Lammi Biological Station, University of Helsinki, Finland

${ }^{\ddagger)}$ Institute of Atmospheric and Earth Sciences, University of Helsinki, Helsinki, Finland

Correspondence: Xiaohong Shi, Water Conservancy and Civil Engineering College, Inner-Mongolia Agricultural University, Hohhot, China, imaushixiaohong63.com

\section{SUMMARY}

1. Winter is a long period of the annual cycle of many lakes in the northern hemisphere. During northern winters, radiation is low and its penetration into the water is restricted by ice and snow cover so that respiration often exceeds primary production leading to low oxygen concentrations.

2. This study was carried out in Inner Mongolia to increase understanding about the under-ice metabolic processes of a shallow lake with relatively high incoming solar radiation on the ice surface in winter due to its southern location and higher light penetration due to the cold-arid climate with little snow cover on the ice. Water column net ecosystem production and respiration during two winters were estimated based on high-frequency measurements of dissolved oxygen using sensors installed under the ice cover.

3. The amount of radiation was the key driver which controlled photosynthesis under ice, while temperature together with photosynthesis seemed to control respiration. The balance between net ecosystem production and respiration was sensitive to changes in the optical properties of ice and water, and particularly to variations in snow cover.

We suggest that shallow lakes in low latitudes with a cold and arid climate and a lack of snow on the ice differ from those in northern latitudes with lower incoming solar radiation and a humid climate with snow on ice, and should be considered as a specific type of ice-covered lakes.

Key words: Lakes, Ecosystem, Wetlands/mires/bogs/marshes, Physical environment, Plankton, Macroalgae, Primary production, Decomposition 


\section{INTRODUCTION}

Relatively little is known of the winter ecology of temperate lakes (e.g. Wetzel, 2001; Salonen et al., 2009; Hampton et al., 2017) due to the fact that research has traditionally focused on the summer season when organisms are usually most active in terms of growth and breeding. About half of inland surface waters in northern hemisphere freeze every year, which means that millions of lakes experience the development of ice cover for shorter or longer time periods. As a result of climate warming, ice-cover season has shortened in a large number of lakes in northern hemisphere (Magnuson et al., 2000; Jackson,2007), where majority of the lakes on the Earth are located (Downing et al., 2006) and the interplay with climate and lakes is strong (Fang \& Stefan, 2009; Brown \& Duguay, 2010).. Since ice cover prevents gas exchange between lake and atmosphere, the balance between photosynthesis $(P P)$ and respiration $(R)$ largely determines the level of dissolved oxygen $(D O)$ concentration under winter ice cover. If $R$ exceeds $P P$, consumption of $D O$ finally leads to anoxia, which may kill many fish and benthic invertebrates and also result in internal loading of phosphorus from sediments (Wetzel, 2001; Baehr, 2002,2004). At the same time accumulation of $\mathrm{CO}_{2}$ and $\mathrm{CH}_{4}$ takes place (Wetzel, 2001; Huotari et al., 2013; Baird, 1987), with these accumulated greenhouse gases rapidly released to the atmosphere at ice-melt.

Due to rather low latitude, incoming solar radiation is much higher than in the temperate zone. In high latitude boreal lakes, winter radiation is low, and usually lakes have snow on the ice, which efficiently prevents light penetration into the lake (Leppäranta, 2015). Therefore, photosynthesis may cease for several months and water temperature is not far from the freezing point and that of the maximum density. Under-ice respiration of bacteria and other microbes as well as higher organisms continues, although low temperature may slow down the metabolic activity of many poikilothermic animals, although even far below the freezing point microbial metabolism may continue at a lo l lif liquid water is available (Price \& Sowers, 2004). In contrast, lakes situated in mid-latitudes with a and cold winter climate, such as the vast Central Eurasia, have attracted even less research than temperate lakes. In such regions the low latitude means incoming solar radiation during winter is higher, while winter precipitation can be extremely low, so that although lakes may have ice-cover for more than four months snow on the ice may be infrequent.

In China, lakes that are situated i ld region, in Nor-Plan and Mountain, Mon-Xin Plateau and QingTibetian Plateau, cover $2 / 3$ of th $\quad$ lake area (Wang \& Dou, 1988), and annually they are covered by ice for 5-7 months. Therefore, under-ice physical, chemical and biological processes have a great relevance in a majority of Chinese lakes, and other studies (e.g. Salonen et al., 2009; Leppäranta, 2015; Hampton et al., 2017) suggest that major changes may result inte the annual cycle of freezing lakes in the course of climate warming. In this study, our primary objective was to increase understanding about under-ice metabolic processes in lakes situated in arid areas in the Eastern Central Eurasian continent. Beeatuse of the low tatitudes, the level of solar fadiat al alhing these water bodies is high even in the middle of winter, and
although the lakes have a thick it er there is little snow on the ice. Our hypotheses were as follows: (i) 

its role in regulating photosynthesis and its impact on water and sediment temperature; and (iii) net ecosystem production in winter is high relative to the ice-covered lakes in northern latitudes, where snow mostly covers ice and causes light limitation.

\section{MATERIAL AND METHODS}

\subsection{Study lake}

The study lake (Wuliangsuhai, WL) in the western part of Inner Mongolia (Fig. 1; 40 $36^{\prime}-41^{\circ} 03^{\prime} \mathrm{N}$, $108^{\circ} 41^{\prime}-108^{\circ} 57^{\prime} \mathrm{E}$, at $1019 \mathrm{~m}$ a.s.l) is the eighth largest freshwater body in China with a total area of about $306 \mathrm{~km}^{2}$. However, only $42 \%$ of its surface area is covered by open water and the rest by dense reed (Phragmites australis) stands (Sun et al. 2013). Typha latifolia, an emergent macrophyte, is also common as well as two submerged species, Stuckenia pectinata (Potamogeton pectinatus) and Myriophyllum verticillatum, both of which occupy extensive parts of the "open water" area. Only at the southernmost edge of the lake are submerged macrophytes, reeds and Typha less abundant. WL belongs to Hetao Basin (5640 $\mathrm{km}^{2}$ ), which is the oldest and third largest irrigation area in China (Guo et al., 2011) and constitutes the northernmost part of the Yellow River drainage basin. WL is a shallow lake with a mean depth of $1.5 \mathrm{~m}$ and volume of $3-4 \times 10^{8} \mathrm{~m}^{3}$ (Zhang et al., 2012; Zhu et al., 2014; Sun et al., 2013). Besides acting as an important water 1 oir, it provides food (fish and crustaceans) for people and biomass (reed) for the paper industry (Köbbing et al., 2013, 2014). It is ecologically and economically a very important water storage, and due to its high biological production provides an interesting site for our study.

Local mean annual air temperature is $7.5^{\circ} \mathrm{C}$ (Zhang et al., 2012; Sun et al., 2013), and annual precipitation and evapotranspiration are Im and $1504 \mathrm{~mm}$, respectively (Zhang et al., 2012; Tao et al., 2015). Water from the Yellow River is pumped to the lake through the main inflow canal located on the western shore of the lake (Fig. 1). The annual amount of water pumped into the lake is approximately $4 \times 10^{8} \mathrm{~m}^{3}$ (Zhang et al., 2012), which approximately equals the volume of the lake. In winter (November-March), usually no or very little water is pumped into the lake, while some wastewater inflow may take place (Sun et al., 2011; Sun et al., 2013). There are practically no other inflows to the lake, and according to Zhu et al. (2014) groundwater inflow to the lake is negligible. The outflow is at the southern end of the lake where a dam is situated. Due to high evapotranspiration to precipitation ratio ( 1 the hydraulic residence time is around 2 years (Zhu et al., 2014).

\subsection{Data acquisition}

To obtain information on evolution of dissolved oxygen concentration $(D O)$ under the ice, high frequency measurements were conducted by MiniDOT sensors (PME, USA) at 10-minute intervals. In winter 2015-16, three sensors were deployed at one sampling point in the southern part of the lake (sampling site S6) at 
depths of $0.70 \mathrm{~m}, 1.06 \mathrm{~m}$ and $2.06 \mathrm{~m}$ below the ice surface, and one sensor was deployed to the main inflow canal $200 \mathrm{~m}$ downstream from the largest pumping station (Fig. 1). The three lake sensors were deployed on 22 January 2016 and were recovered on 10 March 2016. The $D O$ sensor in the main inflow canal recorded from 9 November 2015 to 24 January 2016. In winter 2016-17 we had eight $D O$ sensors at two sites (A, B, see Fig. 1 L15 point), about $10 \mathrm{~m}$ apart. The sensors were deployed on 7 January 2017 and were taken out on 11 March. The $D O$ sensors were situated at depths of $0.46 \mathrm{~m}, 0.96 \mathrm{~m}, 1.21 \mathrm{~m}, 1.46 \mathrm{~m}$ and $1.71 \mathrm{~m}$ (site A) until 20 January and then at $0.55 \mathrm{~m}, 0.80 \mathrm{~m}, 1.05 \mathrm{~m}, 1.30 \mathrm{~m}$ and $1.55 \mathrm{~m}$. At site B the measurement depths were $0.46 \mathrm{~m}, 1.06 \mathrm{~m}$ and $1.66 \mathrm{~m}$ until 20 January and from then $0.60 \mathrm{~m}, 1.10 \mathrm{~m}$ and $1.50 \mathrm{~m}$. When the maximum ice thickness was nearly $0.6 \mathrm{~m}$, the corresponding $D O$ sensor depths relative to the bottom edge of the ice-cover were at minimum -0.05 m (i.e. logger inside ice), $0.20 \mathrm{~m}, 0.45 \mathrm{~m}, 0.70 \mathrm{~m}$ and $0.95 \mathrm{~m}$ (site A), and $\pm 0.00 \mathrm{~m}, 0.50 \mathrm{~m}$ and $0.90 \mathrm{~m}$ (site B). Besides $D O$, the sensors recorded water temperature with an accuracy of $0.1^{\circ} \mathrm{C}$.

Other sensor measurements included water $p H$ (CS526-L, Campbell Scientific, Inc. US), EC (CS547A-L, Campbell Scientific, Inc. US), temperature (CS547A-L, Campbell Scientific, Inc. US), DO (CS511, Campbell Scientific, Inc. US), and turbidity (OBS-3+, Campbell Scientific, Inc. US) at the site B. These sensors were deployed at depths of $0.60 \mathrm{~m}, 1.10 \mathrm{~m}$ and $1.50 \mathrm{~m}$ since 20 January 2017 , and before that, there was only one measuring depth $(0.60 \mathrm{~m})$ for $D O, T w$ and turbidity. The logging interval for most sensors was ten minutes.

In addition to the sensor measurements, ice and water samples were collected on average once every 9 days for laboratory determinations of $\mathrm{pH}$, electrical conductivity, turbidity, $\mathrm{TN}, \mathrm{NH}_{4} \mathrm{~N}, \mathrm{TP}, \mathrm{DIP}, \mathrm{DTP}$, and chlorophyll $a$. An ice saw was used to cut a rectangular prism of about $0.16 \mathrm{~m}^{2}$ horizontal area from which the ice thickness was measured. After that, the ice sample was taken to the laboratory and $0.05 \mathrm{~m}$ thick layers were sliced off and melted separately at room temperature. In addition, a $1.65 \mathrm{~m}$ long device for water sampling was used. The sampler had 33 layers each of $0.05 \mathrm{~m}$ thick When the device was gently lowered down into the water through a hole in the ice, the sampler started to fill with water from the topmost water layer, and water started to move upwards in the device so that gradually the whole device was filled by lake water from the entire water column. All water samples were analyzed in the laboratory of the Observation and Study of Inner Mongolia Wuliangsuhai Wetland Ecosystem Station according to Chinese national standards (see Supplement data). The analytical methods are described in more detail by Wei (2002) and Jiang (2011; see also S1).

The background physical measurements consisted of spectral irradiance (320 - $950 \mathrm{~nm})$ measurements above and under ice by hyperspectral radiometers (RAMSES-ACC-VIS, TriOS Mess- and Datentechnik GmbH, Rastede, Germany), and these data are presented in Cao et al. (2018; submitted manuscript). In the winter 2015-2016, the measurement period was from 12 January to 4 March 2016 but there was a gap in the measurements between 2 February and 19 February due to technical failure. In the winter 2016-2017, the 
optical measurements took place during 31 December 2016 - 9 March 2017 with several short technical breaks. In the winter 2015-2016, three sensors were installed for recording irradiance at 10 min intervals. The sensors above the ice surface consisted of one for downwelling and one for upwelling irradiance at a height of $1.35 \mathrm{~m}$. One sensor installed under the ice at the depth of $1.75 \mathrm{~m}$ was used to measure the transmittance of light through ice and snow. In winter 2016-17, the solar radiation was measured above the ice close to sampling station A. Two sensors were installed $1.00 \mathrm{~m}$ above the ice surface, two under the ice at depths of $0.80 \mathrm{~m}$ and $1.30 \mathrm{~m}$ from the ice surface, and one sensor for reflection from the bottom sediment at a depth of $1.20 \mathrm{~m}$ from the ice surface. Measurements were recorded at an interval of $10 \mathrm{~min}$.

\subsection{Metabolic calculations}

Lake metabolism was calculated from $D O$ concentration data according to Equations (1) following the principles presented by Odum (1956) and Staehr et al. (2010). To estimate the net ecosystem production $(N E P)$ we calculated $D O$ change between each 10 min interval separately for each $D O$ measuring depth and averaged over one hour. Since the $D O$ measurements covered the whole water column, we did not take into account $D O$ change between different layers or diffusion to the sediment and through the ice $(F)$ but averaged the hourly values over the water column. We assumed that no other processes $(A)$ caused changes in $D O$ and thus, $D O$ change equals $N E P$, which is composed of gross photosynthesis $(G P P)$ and community respiration $(R)$.

$\Delta O_{2} / \Delta t=G P P-R-F-A$

$F=0 \mid A=0$

$d O_{2} / d t=N E P$

$N E P=G P P-R$

For estimation of hourly $R$ rate $\left(R_{h r}\right)$ we used averaged NEP during darkness, i.e. including hours when there was no remarkable change in the irradiance and assumed that daylight $R$ equals that during the darkness (Carignan et al., 2000; Cole et al., 2000; Hanson et al., 2003; Staehr et al., 2010; Peeters et al., 2016). For estimation of GPP we used an averaged NEP during the sunlight hours and by subtracting the rate of $R$ according to the Equations (2)

GPPhr = mean NEP sunlight hours + Rhr

GPPday $=$ GPPhr $x 24 h \times$ dayfraction

$R_{h r}\left(g \mathrm{O}_{2} m^{-3} h^{-1}\right)=-$ mean NEPhr during darkness

$N E P_{\text {day }}\left(g \mathrm{O}_{2} m^{-3} d^{-1}\right)=G P P-R_{\text {day }}$ 
Hourly rates were interpolated to daily values by multiplying by 24 for $N E P$ and $R$, while for GPP hourly values were multiplied by the daily light hour fractions based on the PAR (photosynthetically active radiation, 400-700 nm band) measurements. Obtained hourly values were averaged over 4-6 consecutive days to create diurnal pattern over these 4-6 day periods. The length of the averaging period of the diurnal pattern of $N E P$ was adjusted to make visible the effect of snow cover on ice. All $R$ results are presented as negative values in the figures.

Because we had a more complete set of instruments on the field in winter 2016-2017 than in winter 20152016 , in this paper we focus mainly on the results from the second winter. The first winter results are shown as supplementary data in order to help better understand the metabolic processes and/or their interactions with the physical and chemical conditions/properties. Mostly the results of both winter seasons are in good agreement. However, when the sampling sites were different in 2015-2016 and 2016-2017, some sitespecific characteristics were evident in the data sets; only some of those (most important results of winter 2015-2016) are highlighted in this paper.

Statistical methods applied include correlation and regression analyses. All statistical calculations were carried out using Microsoft Office.

\section{RESULTS}

In both winter seasons of the study (2015-16 and 2016-17) the maximum ice thickness of $0.6 \mathrm{~m}$ was reached at the end of February. Although the ice was mostly snow-free, during the first winter there were 7-day and 12-day periods (11-18 February and 18 February - 2 March) when a thin snow cover (max. $4 \mathrm{~cm}$ and $7 \mathrm{~cm})$ was laying on top of the ice. During the second winter there were two short snow periods in February; the first started on 7 February and continued until 21 February with a snow depth of $3 \mathrm{~cm}$ and the second started on 22 February and continued until 3 March with less than $1 \mathrm{~cm}$ of snow. In winter 2015-16 ice-on took place in 19 November and ice-off in 17 March, while in 2016-2017 the respective dates were 14 November and 29 March. During the ice season 2015-16 the minimum and maximum air temperatures were $-25.0{ }^{\circ} \mathrm{C}$ and $+16.4{ }^{\circ} \mathrm{C}$ and during $2016-17-25.0{ }^{\circ} \mathrm{C}$ and $+11.0^{\circ} \mathrm{C}$. Minimum values were recorded in JanuaryFebruary and maximum values in February-March.

\subsection{Irradiance and water temperature}

In the study lake the mid-day under-ice irradiance was typically $>20 \mathrm{~W} \mathrm{~m}^{-2}$, except during periods with snow (maximum ca $3 \mathrm{~cm}$ ) on the ice. After two snowfall events in February 2017 (Julian day 38 and 52), the impact of snow on light penetration into the lake was clearly demonstrated: $P A R$ at $0.80 \mathrm{~m}$ depth decreased from $10-11 \%$ to $1 \%$ relative to the incoming PAR at the lake surface. Thus, the attenuation coefficient of the ice was within $2.5-3 \mathrm{~m}^{-1}$, and the large reduction by the thin snow cover was due to both snow albedo and attenuation in snow. Without snow, the high irradiance heated up the entire water column and resulted in a clear diurnal variation in water temperature (S2), althoı, vertical water mixing was observed. In 
February 2017, when there was snow on ice and water temperature decreased at all measurement depths, no water mixing between the different layers took place. Only during a warming period at the very end of the study season in March 2017 was a mixing event evident. In contrast, in winter 2015-16 the temperature data indicated a few short mixing events between the surface and bottom (S2). The results from the two winter seasons show indisputably how effectively solar irradiance controls under-ice water temperature in WL. The impact was clear both at the diurnal and at the seasonal time-scales.

In winter 2015-2016 the maximum recorded water temperature near the bottom was $7.4{ }^{\circ} \mathrm{C}$, and in 2016 2017 the value of $7.5^{\circ} \mathrm{C}$ was nearly the same. During the second winter the variation was largest (from 0.7 to $6.2^{\circ} \mathrm{C}$ ) at the second uppermost depth and decreased down to the lake bottom (from 4.4 to $7.5^{\circ} \mathrm{C}$ ), being smallest $\left(-0.1\right.$ to $\left.2.3^{\circ} \mathrm{C}\right)$ just below the ice (S2).

\subsection{Water chemistry}

The results of the chemical analyses are summarized in S3 and chemical stratification in S4. In general, temperature stratification was accompanied by chemical stratification. According to the electrical conductivity $(E C)$ results of both sensors and manual sampling, the stratification of dissolved ions was weak but stable. Water density was lowest immediately beneath the ice and increased towards the middle and lower depths. This is a highly delicate balance since around $4^{\circ} \mathrm{C}$ temperature influence on density is very small and can be compensated by small changes in $E C$. Also, the presence of ice cover prevents forced mixing by wind. Under the ice, lake water $\mathrm{pH}$ was high and $\mathrm{TP}, \mathrm{TN}, \mathrm{NH}_{4}-\mathrm{N}$ and chlorophyll $a$ concentrations were relatively high as well. In contrast, $E C$ and turbidity values were low.

In the ice, the nutrient concentrations were usually higher in the topmost surface layer than in the lowermost part, while in the water column the highest concentrations were found closer to the sediment rather than in the upper layers. In agreement with this, hydrogen ion concentration increased towards the bottom and resulted in a decrease in water $p H$ near the bottom. The $p H$ results obtained by the sensors agreed well with the laboratory analyses, while the sensors gave slightly higher $E C$ values than those of manual samples. The concentrations of $T P, T N$ and $C h l a$ increased substantially below $1.20 \mathrm{~m}$ depth, and the turbidity gradient was strongest close to the bottom.

In the ice, $C h l a$ concentration was very low $\left(<0.8 \mathrm{mg} \mathrm{m}^{-3}\right)$, but under ice the average $C h l a$ concentration was substantially higher, gradually decreasing from January $\left(14.6 \mathrm{mg} \mathrm{m}^{-3}\right)$ to February $\left(11.4 \mathrm{mg} \mathrm{m}^{-3}\right)$ and to March $\left(2.9 \mathrm{mg} \mathrm{m}^{-3}\right)$. Chl a concentration tended to increase towards the bottom; in January a clear upward shift took place at a depth of $0.80 \mathrm{~m}$ and at the beginning of March at a depth of $1.50 \mathrm{~m}$. However, in February no vertical variation was found.

In the water column, the mean concentration of total phosphorus $(T P)$ during the different sampling occasions explained 54\% of the variability of the chlorophyll $a$ concentration, but if all vertical samples were 
considered the relationship between $C h l a$ and $T$. very weak $\left(\mathrm{r}^{2}=0.076\right)$. However, during the last sampling on 11 March, TP explained $68 \%$ of the variability of $C h l a$ at different depths

\subsection{DO evolution}

$D O$ evolution during the two winter periods can be seen in Figs 2-4. In January 2017, DO concentrations were high (maximum $>25 \mathrm{mg} \mathrm{L}^{-1}$ ) at the uppermost three sampling depths, but the concentrations declined in February simultaneously with two snowfall events and subsequent reduction in irradiance under ice. At the end of February, the concentrations were already below $5 \mathrm{mg} \mathrm{L}^{-1}$ in the whole water column. The concentration decreased fastest just under the ice and more slowly in deeper water. As a result, in the topmost water layer $D O$ concentration became lower until the middle of February than in the rest of the water column. The exception was the water layer closest to the bottom sediment where $D O$ concentration was mostly below $5 \mathrm{mg} \mathrm{L}^{-1}$ and from the first week of February below the detection limit $\left(<0.3 \mathrm{mg} \mathrm{L}^{-1}\right)$. As with temperature, the diurnal pattern of $D O$ concentration followed the solar radiation (Figs 5-8). The pattern prevailed as long as substantial irradiance $\left(>10 \mathrm{~W} \mathrm{~m}^{-2}\right)$ penetrated into the lake, i.e. from January to the first week of February, five days after mid-February, and in the beginning of March. The diurnal pattern was stronger at the two deepest depths than in the topmost layer. In agreement with the temperature measurements, $D O$ results in winter 2016-2017 did not reveal any complete mixing between the water layers (Figs. 3-4). However, the situation was slightly different in winter 2015-2016, when during two short time periods most of the water column was mixed, at least between the bottom and the middle layer (Fig 2 and $\mathrm{S} 2)$.

\subsection{Ecosystem metabolism}

In the diurnal cycle, the net ecosystem production $(N E P)$ was, on average, positive in January only during three hours, in February during 4-5 hours, and in March during 10-11 hours (Fig. 5). The rest of the day respiration $(R)$ was equal to $D O$ production or higher. In February and March, the diurnal pattern of gross primary production $(G P P)$ and $R$ was especially clear. In January, net $D O$ production took place late in the evening, i.e. 7-9 p.m., which suggests that processes other than photosynthesis were responsible for the increase in $D O$ concentration. In the afternoon net $D O$ production declined rapidly after 4 p.m., parallel with a decrease in the incoming $P A R$ over the s $\quad e<500 \mathrm{~W} \mathrm{~m}^{-2}$, after which the $D O$ consumption exceeded $D O$ production.

As a result of the balance between primary prodı_ and ecosystem respiration, the net ecosystem production $(N E P)$ was close to zero from January until the first snowfall in February, when $N E P$ declined and became negative (Fig 6). After snowmelt, a few days later, NEP recovered back to zero but after the second snowfall in February, it again turned negative. Finally, in March, when ice started to melt and daily irradiance increased due to higher solar altitude, longer daylight hours, and lower albedo, NEP increased and became positive (Fig. 6). From the middle of February daily GPP followed very closely the daily variation of 
$\operatorname{PAR}\left(\mathrm{R}^{2}=0.7761, \mathrm{p}<0.001\right.$; Fig. 7). In winter 2015-2016, DO concentration started to increase rapidly at the beginning of March in close interplay with $P A R$. The results indicated that with light intensity $<2 \mathrm{~W} \mathrm{~m}^{-2}$, i.e. at the deeper depth $(1.055 \mathrm{~m})$, there was no clear connection between $D O$ and PAR while near the surface $(0.7 \mathrm{~m})$ with $P A R>2 \mathrm{~W} \mathrm{~m}^{-2}$ the relationship was very strong (Fig.8).

Although in winter 2016-2017 at the two sites (A and B) water temperature and $D O$ results were close to each other, they differed regarding $D O$ evolution at the beginning of March, at the time of a rapid increase in $P A R$ due to snow and ice melt. Together with fewer macrophytes at $\mathrm{A}$, the rate of increase in $D O$ concentration was $25 \%$ higher than in B (Fig. 9).

\section{DISCUSSION}

The results demonstrated that, except for a few short snow cover periods, irradiance was high enough under ice to support photosynthesis during the winter months. This means that in this shallow lake, under bare ice photosynthesis prevails. This is in accordance with Obertegger \& Obrador(2017) who analyzed under-ice $D O$ dynamics based on high-frequency $(H F)$ data at two depths (5 and $25 \mathrm{~m})$ for three winters (JanuaryMarch 2014, 2015, and 2016) in oligotrophic Lake Tovel. Due to snow periods, in January and February $N E P$ was negative, suggesting that ecosystem respiration exceeded gross primary production $(G P P)$. Thus, our results show that in shallow lakes in low latitudes and with an arid and cold winter, photosynthetic activity may continue through the whole winter. In the Eurasian continent the number of such lakes is large although we have only little information on such lakes (see World Lake Database, International Lake Environment Committee, ILEC; http://wldb.ilec.or.jp/). However, when even a thin snow cover limits light penetration into a lake (Leppäranta, 2015), a prerequisite for photosynthesis is that there will be no snow on the ice. In northern latitudes, light limitation can be severe during the middle winter due to low total irradiance and snow on the ice (Leppäranta, 2015; Hampton et al., 2017).

Besides photosynthesis, in our study lake water temperature was also dramatically influenced by solar irradiance. The results suggest that longer waves of $P A R$ reached the bottom sediment and kept the deepest water layer warm as long as there was no snow on the ice. As soon as the irradiance decreased, a rapid decrease in water temperature was accompanied by a near absence of diurnal variation. When irradiance rose again, water temperature started to increase and diurnal variation strengthened. It should be noted that water temperature fluctuated diurnally in the entire water column, a phenomenon that was a result of the shallow (less than the optical depth) water. The conditions are therefore different than in northern latitude and high elevation lakes with low incoming solar radiation and snow cover on the ice (Salonen et al., 2009; Hampton et al., 2017).

The results imply that the heat balance of the lake is very sensitive to the incoming solar radiation during the winter season. The heat storage accumulated during the previous open-water season strongly influenced 
thermal conditions in the sediment and in the water column, and partly explains why water temperature above the sediment remained $>6^{\circ} \mathrm{C}$ until the beginning of February in winter 2016-17, i.e.for more than two months after the ice-on. Since temperature is a key variable affecting metabolic processes of organisms and, in particular, their respiration, the observed water and sediment temperatures in WL support high respiration activity. Therefore, it was not a surprise that the balance between GPP and $R$, i.e. $N E P$, was very sensitive to the level of irradiance in the lake. Ecosystem $R$, in turn, is also influenced by the availability of organic matter that was obvious in the study lake where $R$ increased parallel with photosynthesis. The results suggest that primarily the same factors are influencing $R$ both in winter and summer. Thus, when $P P$ was limited by $P A R, R$ dominated over $P P$ and $D O$ concentration decreased, which might lead to anoxia in the lowermost part of the water column, as was noticed in winter 2015-2016 in the slightly deeper sampling site S6.

Sun et al. (2013) have earlier pointed out that in WL low DO concentration in winter is caused by several factors: prevented gas exchange between water and atmosphere, greatly reduced photosynthesis because of low irradiance and low water temperature, and transfer of organic pollutants into water due to freezing resulting in an increase in $D O$ consumption. Although the conditions may differ between different winters due to changes in weather and amount of water pumped into the lake (see Sun et al., 2013), our results stressed the importance of factors other than those proposed by Sun et al. (2013). Although it is not easy to determine the role of different factors controlling DO (e.g. Leppi et al., 2016), our results clearly demonstrated that in the study lake under-ice irradiance was high enough to support photosynthesis over the whole winter except for two short periods in February when snow was on the ice. In WL water temperature was also high relative to many other ice-covered lakes (e.g. Hampton et al., 2017) and may not greatly depress the photosynthetic activity of winter phytoplankton. The impact of low temperature on the photosynthesis of benthic and epiphytic algae, as well as macrophytes remains unknown, although our earlier observations indicate that the upper shoots of the dominant submerged plants S. pectinata and M. verticillatum may be broken under ice. We suggest that the exceptionally high $D O$ concentration in the topmost water layer in January as well as the late evening increase in $D O$ and $N E P$ during darkness were caused by the release of $D O$ during freeze-out. This process was instrated in the laboratory (see supplement data), and the results confirmed the field observations.

The observed higher increase of $D O$ concentration near the bottom relative to the surface in March cannot be explained by the effect of temperature on the solubility of oxygen, because of higher bottom temperature relative to the surface. Instead, the higher bottom $D O$ increase might be caused by dilution of $D O$ in the surface due to ice melting and by benthic photosynthesis. The higher increase in water temperature near the surface might be caused, in turn, by higher irradiance close to the surface. This result was a bit unexpected, however, because ice-melt releases very cold, low-density water to the topmost water layer. In spite of that no major density gradients in the water column existed, a phenomenon difficult to explain in light of the observed gradient in temperature. Although the sampling device may have caused some interference between 
the different water layers (see Material and methods), sensor data followed rather well the lab measurements of EC. Temperature difference between surface and bottom, i.e. between $0^{\circ} \mathrm{C}$ and $8^{\circ} \mathrm{C}$, was therefore the most important factor influencing the density stratification. However, we lack data for dissolved gases, which may affect the density. The density gradient, although weak, was inevitable because otherwise temperature values $>6^{\circ} \mathrm{C}$ would not be possible close to the bottom sediment. Interestingly, in winter 20162017 the results did not show any mixing events while in the previous winter a few abrupt mixing events occurred. We expect these events to be caused by inflow of water, which was pumped into the lake rather than by in-lake processes or differences in weatt lditions. The sampling site in winter 2015-2016 was located in the southern and slightly deeper part c_..._. ake, relatively close to a pumping station. High accuracy for the measurements of temperature and electrical conductivity is essential because even small gradients in dissolved ions, i.e. ionic strength, may contribute to stratification and mixing in freshwater under ice (Kirillin et al., 2012). It should be noted that water temperature near the bottom was close to the mean annual air temperature of the region $\left(\sim 7.5^{\circ} \mathrm{C}\right)$, suggesting that the sediment can be heated by solar radiation also during the winter.

Guo et al. (2011) have suggested that dissolved organic matter dynamics in WL are strongly affected by human activities. $\mathrm{H} \longrightarrow$, our results indicate that autochthonous production of organic matter should not be underrated because it has high relevance regarding ecosystem respiration, which is a good indicator of the status of a water body (Odum, 1956; Burns, 1995; Cole et al., 2000; Pace \& Prairie, 2005). In the case of WL that makes sense because it is known to be a highly eutrophic lake and wetland system. wo snowfalls in February were especially demonstrative, because snow on the ice decreased water temperature at all measurement depths. That shows indisputably how strongly irradiance controlled under-ice water temperature in the study lake. The impact was strong at both the diurnal and the seasonal time-scales. After snow melt and the consequent irradiance increase in the lake, water temperature also started to increase in the entire water column, demonstrating the key role of snow and irradiance.

During freezing of lake water, macro- and micronutrients and pollutants are released from the growing ice to the liquid water body (Pieters \& Lawrence, 2009; Yang et al., 2016; Canfield, 1983), and the same happens to DO as our lab experiments and field measurements show. This observation is in accordance with Meding \& Jackson (2001), who proposed, based on data from 23 North American temperate lakes, that DO inputs through photosynthesis and ice growth together with simultaneous freeze-out are more important in shallow lakes than in deep lakes, although in their data set the role of freeze-out was rather marginal. In our study lake, freeze-out in December-February enhanced the DO and nutrient concentrations just beneath the ice while in March, during the rapid ice-melt, dilution took place and decreased the DO as well as other element concentrations. Atmospheric deposition, on the other hand, enriched the uppermost surface of the ice with dust and other elements, which was obvious especially at the end of the study period in March, and demonstrated by elevated EC level. 
The relatively high Chl $a$ concentration, which was consistent with Guo et al. (2011) and also in the range given by Hampton et al. (2017), supported the hypothesis that photosynthesis continued throughout the whole winter except for periods when snow covered the ice. In March, photosynthesis was suppressed, and in the lower part of the water column Chl $a$ concentration increased. Due to the respiration of microbes in the sediment, $\mathrm{CO}_{2}$ was released to the water and resulted in the lowest $\mathrm{pH}$ close to the sediment, similar to the results of Leppäranta et al. (2012) from Lake Vanajanselkä, Finland.

A snow layer only a few centimetres thick on the ice over a few weeks may cause rapid DO overconsumption (Mathias \& Barica, 1980; Meding \& Jackson, 2001, 2003) and finally lead to anoxia with severe consequences to the ecosystem such as fish kills (see Greenbank, 1945; Barica \& Mathias, 1979; Fang \& Stefan, 2000; Ruuhijärvi et al., 2010). In shallow and eutrophic water systems similar to the study lake and lacking snow cover, under-ice winter photosynthesis prevents appearance of anoxia, otherwise common in such lakes with a long ice season (Meding \& Jackson, 2001).

\section{CONCLUSIONS}

Water bodies similar to WL without snow on the ice should be considered a special type of ice-covered lakes, because in such lakes photosynthetic activity can continue at relatively high level under ice over the winter season. The conditions are therefore different than in northern latitude and high elevation lakes with low incoming solar radiation and snow on the ice. Any major change in winter precipitation and/or air pollution may affect the amount and quality of incoming solar radiation and affect the metabolic processes in the lakes. Regarding the ecosystem metabolism under ice, such lakes can be considered especially vulnerable to changes in atmospheric conditions and climate change.

\section{Acknowledgments}

We want to thank all students and staff -members of the Inner-Mongolia Agricultural University and Dalian University of Technology, who have worked in the field and laboratory, as well technicians of Lammi Biological Station, University of Helsinki, for their invaluable help. The work was supported by the National Natural Science Foundation of China (51339002 for Changyou, 51669022, 51269017 for Xiaohong 51509133 for Shengnan, 51811530388 for Xiaohong and Shengnan, 51579028 for Zhijun), the National Forestry and Grassland Administration of China (2018-LYPT-DW-019 for Xiaohong), the Inner Mongolia Autonomous Region Science and Technology Department (2016MS0406 for Xiaohong) and the Academy of Finland (grants No 311520, No 316866 for JH, grants No 318562 for TT, grants No 318164 for SU, grants No 316306 for ML, grants No 310997, No 315527, No 314758 for LA ). Shuang Song was funded by the China Scholarship Council for her one year visiting in Lammi Biological Station. We also want to thank prof. Roger Jones for his valuable comments and English corrections.

We declare no conflict of interests with any commercial or other interest. 


\section{References}

Baehr, M.M., \& DeGrandpre, M.D. (2002). Under-ice CO2 and O2 variability in a freshwater lake. Biogeochemistry, 61, 95-113. DOI: $10.1023 / \mathrm{A}: 1020265315833$

Baehr, M.M., \& DeGrandpre, M.D. (2004). In situ pCO2 and DO dynamics during turnover and stratification in Lake Placid, Montana, USA, and observed light driven mixing and net metabolism under ice before ice break-up. Limnology \& Oceanography, 49 (2): 330 - 340. DOI: 10.4319/lo.2004.49.2.0330

Baird, D. J., Gates, T. E., \& Davies, R. W. (1987). Oxygen conditions on two pothole lakes during winter ice cover. Canadian Journal of Fisheries and Aquatic Sciences, 44 (5), 1092-1095. DOI: 10.1139/f87-131

Barica, J., \& Mathias, J. A. (1979). Oxygen depletion and winterkill risk in small prairie lakes under extended ice cover. Canadian Journal of Fisheries and Aquatic Sciences, 36 (8), 980-986. DOI: 10.1139/f79-136

Brown L.C. \& Duguay C.R. (2010). The response and role of ice cover in lake-climate interactions. Progress in Physical Geography, 34 (5), 671-704. DOI: 10.1177/0309133310375653

Burns, N.M. (1995). Using hypolimnetic dissolved oxygen depletion rates for monitoring lakes. New Zealand Journal of Marine and Freshwater Research, 29, 1-11. DOI: 10.1080/00288330.1995.9516634

Canfield, D. E. Jr., Bachmann, R. W., \& Hoyer, M. V. (1983). Freeze-out of salts in hard-water lakes. Limnology \& Oceanography, 28 (5), 970-977. DOI: 10.4319/10.1983.28.5.0970

Carignan.R, Planas,D, \& Vis.C. (2000). Planktonic production and respiration in oligotrophic Shield lakes. Limnology \& Oceanography, 45:189-199. DOI: 10.4319/10.2000.45.1.0189

Cole, J.J., Pace, M.L., Carpenter, S.R. \& Kitchell, J.F. (2000). Persistence of net heterotrophy in lakes during nutrient addition and food web manipulations. Limnology \& Oceanography, 45 (8),1718-1730. DOI:10.4319/1o.2000.45.8.1718

Downing J.A., Prairie Y.T., Cole J.J., Duarte C.M., Tranvik L., Striegl R.G., McDowell W.H., Kortelainen P., Caraco N.F., Melack J.M. \& Middelburg J.J. (2006). The global abundance and size distribution of lakes, ponds, and impoundments. Limnology \& Oceanography, 51 (5), 2388-2397. DOI: 10.4319/10.2006.51.5.2388

Fang, X., \& Stefan, H. G. (2000). Projected climate change effects on winterkill in shallow lakes in the northern United States. Environmental Management, 25 (3), 291-304. DOI: 10.1007/s002679910023

Fang, X., \& Stefan, H. G. (2009). Simulations of climate effects on water temperature, dissolved oxygen, and ice and snow covers in lakes of the contiguous United States under past and future climate scenarios. Limnology \& Oceanography, 54 (6), 2359-2370. DOI: 10.4319/lo.2009.54.6_part_2.2359

Greenbank, J. (1945). Limnological conditions in ice-covered lakes, especially as related to winter-kill of fish. Ecological Monographs, 15 (4), 343-392. DOI: 10.2307/1948427

Guo, X.J., Xi B.D., Yu, H.B., Ma, W.C., \& He, X.S. (2011). The structure and origin of dissolved organic matter studied by UV-vis spectroscopy and fluorescence spectroscopy in lake in arid and semi-arid region. Water Science and Technology. 63 (5), 1010-1017. DOI: 10.2166/wst.2011.283

Hampton, S. E., Galloway, A. W. E., Powers, S. M., Ozersky, T., Woo, K. H., Batt, R. D., Xenopoulos, M. A. et al. (2017). Ecology under lake ice. Ecology Letters, 20, 98-111. DOI: 10.1111/ele.12699

Hanson, P.C., Bade, D.L., Carpenter, S.R., \& Kratz, T.K. (2003). Lake metabolism: Relationships with dissolved organic carbon and phosphorus. Limnology \& Oceanography, 48 (3), 1112-1119. DOI: 10.4319/lo.2003.48.3.1112

Huotari.J, Nykanen.H, Forsius.M, \& Arvola.L. (2013). Effect of catchment characteristics on aquatic carbon export from a boreal catchment and its importance in regional carbon cycling. Globle Change Biology. 19 (12), 3607-3620. DOI: $10.1111 /$ gcb.12333 doi:10.1111/gcb.12333

Jackson, L. J., Lauridsen, T. L., Søndergaard, M. \&Jeppesen, E. (2007). A comparison of shallow Danish and Canadian lakes and implications of climate change. Freshwater Biology, 52 (9), 1782-1792. DOI: 10.1111/j.13652427.2007.01809.x

Jiang, H.Q. (2011). Experimental Study on the Spatial Distribution of Nutrient Salts in the Ice of Lake Wuliangsuhai and Their Release Processes during Melting, Inner Mongolia Agricultural University, 20-23 
Kirillin, G., Leppäranta, M., Terzhevik, A., Granin, N., Bernhardt, J., Engelhardt, C., \& Zdorovennova G. (2012). Physics of seasonally ice-covered lakes: a review. Aquatic Sciences, 74 (4), 659-682. DOI: 10.1007/s00027-012-0279-y

Köbbing, J.F. \& Thevs, N. (2013). Ecosystem Services of Wuliangsuhai Lake: Case study from Inner Mongolia, China. 6th Sino-German Workshop on Biodiversity Conservation TEEB for Cities and Urban-Rural Interactions 15-18 July 2013, Bonn, Germany.

Köbbing, J.F., Patuzzi, F., Baratieri, M., Beckmann, V., Thevs, N. \& Zerbe, S. (2014). Economic evaluation of common reed potential for energy production: A case study in Wuliangsuhai Lake (Inner Mongolia, China). Biomass and Bioenergy, 70,315-329. DOI: 10.1016/j.biombioe.2014.08.002

Leppi, J., Arp, C. \& Whitman, M. (2016). Predicting late winter dissolved oxygen levels in arctic lakes using morphology and landscape metrics. Environmental Management, 57 (2), 463-473. DOI: 10.1007/s00267-015-0622-x

Leppäranta, M. (2015). Freezing of Lakes and the Evolution of their Ice Cover. Springer-Verlag Berlin Heidelberg. DOI10.1007/978-3-642-29081-7

Leppäranta, M., Heini, A., Jaatinen, E. \& Arvola, L. (2012).The influence of ice season on the physical and ecological conditions in Lake Vanajanselkä, southern Finland. Water Quality Research J. Canada 47 (3-4), 287-299. DOI: 10.2166/wqrjc. 2012.003

Magnuson, J. J., Robertson, D. M., Benson, B. J., Wynne, R. H., Livingstone, D. M., Arai, T., \& Vuglinski V. S. (2000). Historical trends in lake and river ice cover in the northern hemisphere. Science, 289 (5485), 1743-1746. DOI: $10.1126 /$ science. 289.5485 .1743

Mathias, J. A., \& Barica, J. (1980). Factors controlling oxygen depletion in ice-covered lakes. Canadian Journal of Fisheries and Aquatic Sciences, 37 (2), 185-194. DOI: 10.1139/f80-024

Meding, M. E., \& Jackson, L. J. (2001). Biological implications of empirical models of winter oxygen depletion. Canadian Journal of Fisheries and Aquatic Sciences, 58 (9), 1727-1736. DOI: 10.1139/cjfas-58-9-1727

Meding, M. E., \& Jackson, L. J. (2003). Biotic, chemical, and morphometric factors contributing to winter anoxia in prairie lakes. Limnology \& Oceanography, 48 (4), 1633-1642. DOI: 10.4319/1o.2003.48.4.1633

Obertegger.U, Obrador.B, \& Flaim.G. (2017). Dissolved oxygen dynamics under ice: Three winters of high-frequency data from Lake Tovel, Italy. Water Resources Research, 53 (8), 7234-7246. DOI: 10.1002/2017WR020599

Odum, H.T. (1956). Primary production in flowing waters. Limnology \& Oceanography. 1 (2), 102-117. Doi: 10.4319/lo.1956.1.2.0102

Pace, M. \& Prairie, Y.L. (2005). Respiration in lakes, p. 103- 121. In: P. A. del Giorgio \& P. J. B. Williams [1st ed.], Respiration in aquatic ecosystems. Oxford Univ. Press. DOI: http://dx.doi.org/10.1093/acprof:oso/9780198527084.003.0007

Peeters, F., Atamanchuk, D., Tengberg, A., Encinas-Fernández, J., \& Hofmann, H. (2016). Lake metabolism: Comparison of lake metabolic rates estimated from diel CO2 and the common diel $\mathrm{O}_{2}$ technique. PLoS ONE. 11 (12), e0168393. DOI: 10.1371/journal.pone.0168393

Pieters, R. \& Lawrence, G.A. (2009). Effect of salt exclusion from lake ice on seasonal circulation. Limnology \& Oceanography. 54 (2), 401-412. DOI: 10.4319/1o.2009.54.2.0401

Price, P.B. \& Sowers, T. (2004). Temperature dependence of metabolic rates for microbial growth, maintenance, and survival. Proc Natl AcadSci U S A. 101(13), 4631-4636. DOI: 10.1073/pnas.0400522101

Ruuhijärvi, J., Rask, M., Vesala, S.,Westermark, A. \& Lehtovaara, A. (2010). Recovery of the fish community and changes in the lower trophic levels in a eutrophic lake after a winter kill of fish. Hydrobiologia. 646, 145-158.

DOI10.1007/s10750-010-0186-y

Salonen, K., Leppäranta, M., Viljanen, M. \& Gulati, R. D. (2009). Perspectives in winter limnology: closing the annual cycle of freezing lakes. Aquatic Ecology. 43 (3), 609-616. DOI: 10.1007/s10452-009-9278-Z

Staehr, P.A., Bade, D., Van de Bogert, M.C., Koch, G.R., Williamson, C., Hanson, P., Cole, J.J. \& Kratz, T. (2010). Lake metabolism and the diel oxygen technique: State of the science. Limnology \& Oceanography: Methods. 8, 628644. DOI 10.4319/lom.2010.8.628 
Sun, B., Li, C.Y. \& Zhu, D.N. (2011). Changes of Wuliangsuhai Lake in past 150 years based on 3S technology. Proceedings of 2011 International Conference on Remote Sensing, Environment and Transportation Engineering. 2993 - 2997. DOI: 10.1109/RSETE.2011.5964944

Sun, B., Li, C.Y., Cordovil, C.M.D.S., Jia, K.L, Zhang, S., de Varennes, A. \& Pereira, L.S. (2013). Variability of water quality in Wuliangsuhai Lake receiving drainage water from Hetao Irrigation system in Yellow River Basin, China. Fresenius Environmental Bulletin, 22 (6), 1666-1676.

Tao, S.L., Fang, J.Y., Zhao, X., Zhao, S.Q., Shen, H.H., Hu, H.F., Tang, Z.Y., Wang, Z.H., \& Guo, Q.H. (2015). Rapid loss of lakes on the Mongolian Plateau. Proceedings of the National Academy of Sciences of the United States of America. 112 (7), 2281-2286. DOI: 10.1073/pnas.1411748112

Wang, S.M \& Dou, H.S. (1988). Chinese Lakes, Beijing, Science Press

Wetzel, R.G. (2001). Limnology - lake and river ecosystems ( $3^{\text {rd }}$ ed.). Academic Press, San Diego, CA.

Wei, F.S. (2002). Water and wastewater monitoring analysis method (4th ed.). China environmental science press

Wissel, B., Quiñones-Rivera, Z. J., \& Fry, B. (2008). Combined analyses of O2 and CO2 for studying the coupling of photosynthesis and respiration in aquatic systems. Canadian Journal of Fisheries and Aquatic Sciences, 65 (11), 2378 2388. https://doi.org/10.1139/F08-146

Yang, F., Li, C.Y., Leppäranta, M., Shi, X.H., Zhao, S.N., \& Zhang, C.F. (2016). Notable increases in nutrient concentrations in a shallow lake during seasonal ice growth. Water Science and Technology. 74 (12), $2773-2883$.

DOI: $10.2166 /$ wst.2016.433

Zhang, Y.M., Jia, Y.F., Jiao, S.W., Zeng, Q., Feng, D.D., Guo, Y.M. \& Lei, G.C. (2012). Wuliangsuhai Wetlands: A Critical Habitat for Migratory Water Birds. Journal of Resources and Ecology, 3 (4), 316-323.

DOI:10.5814/j.issn.1674-764x.2012.04.004

Zhu, D. N, Cathryn, R., M., Sun, B., \& Li, C.Y. (2014). The influence of irrigation and Wuliangsuhai Lake on groundwater quality in eastern Hetao Basin, Inner Mongolia, China. Hydrogeology Journal. 22 (5), 1101-1114. DOI 10.1007/s10040-014-1116-2 
Figures caption list

Fig. 1 Location of Lake Wuliangsuhai in Inner Mongolia, northern China (A). The study lake with open water areas (indicated by dark grey), reed stands (light grey), sampling sites (dots), inflowing canals (indicated by arrows in W shore) and outflow (indicated by arrow in SW corner) (B).

Fig. 2 DO concentrations at three different depths in Wuliangsuhai in winter 2015-2016. Thick black line indicates the depth of $0.70 \mathrm{~m}$ below the ice surface, grey $1.06 \mathrm{~m}$, and thin black $2.06 \mathrm{~m}$, respectively. The measurements started January 23 and continued until March 10. The depth of the water was $2.20 \mathrm{~m}$.

Fig. 3 DO profile at site A of Wuliangsuhai drawn with isolines at $2 \mathrm{mg} \mathrm{DO} \mathrm{m}^{-3}$ intervals since January 20 until March 11 in winter 2016-2017. Black broken line denotes ice thickness, i.e. the lower surface of the ice cover.

Fig. 4 DO concentrations at two different depths at site B in Wuliangsuhai in winter 2016-2017. Thick black line indicates DO at top depth, and grey indicates middle depth, respectively. The measurements started January 7 and continued until March 11. Records taken at 10 minute intervals are given as running averages for 30 minutes. The total depth of water was $1.72 \mathrm{~m}$. The bottom DO values were always below $0.2 \mathrm{mg} \mathrm{L}^{-1}$. Thin black lines indicate PAR at $0.80 \mathrm{~m}$ below the ice bottom, the DO measurement depths were $0.46 \mathrm{~m}$, $1.06 \mathrm{~m}$ and $1.66 \mathrm{~m}$ until 20 January and since then $0.60 \mathrm{~m}, 1.10 \mathrm{~m}$ and $1.50 \mathrm{~m}$.

Fig. 5 Diel variation in NEP in winter 2017. Note: the time periods for which the calculations were done are not equal (see Material and methods).

Fig. 6 GPP (black dots), R (white dots) and NEP (small dots) in January-March 2017.

Fig. 7 Daily GPP relative to photosynthetically active radiation (PAR) since the middle of February 2017.

Fig. 8 Daily average DO concentrations (y-axes) relative to photosynthetically active radiation (PAR, xaxis) between 1-9 March 2016. Black dots indicate DO and PAR at the depth of $0.70 \mathrm{~m}$ and white dots at the depth of $1.06 \mathrm{~m}$.

Fig. 9 Daily average water column DO concentrations (y-axes) from 1 March 2017. White markers DO values in the first measurement site (A) with less macrophytes, and black dots indicate DO values in the second measurement site (B) with more macrophytes. White dots show results based on 3 sensors at equal depths as in site B, and white squares on 5 sensors (for details see material and methods). 
Figures
A.
B

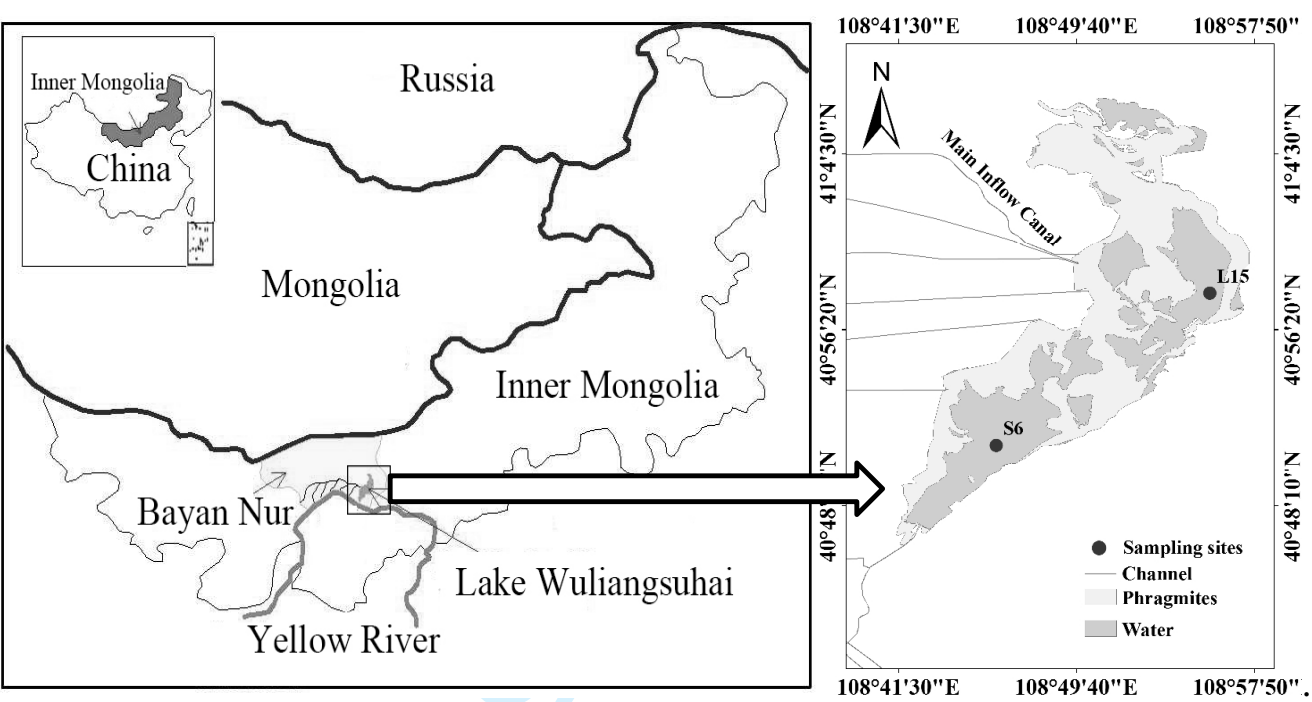

Fig. 1

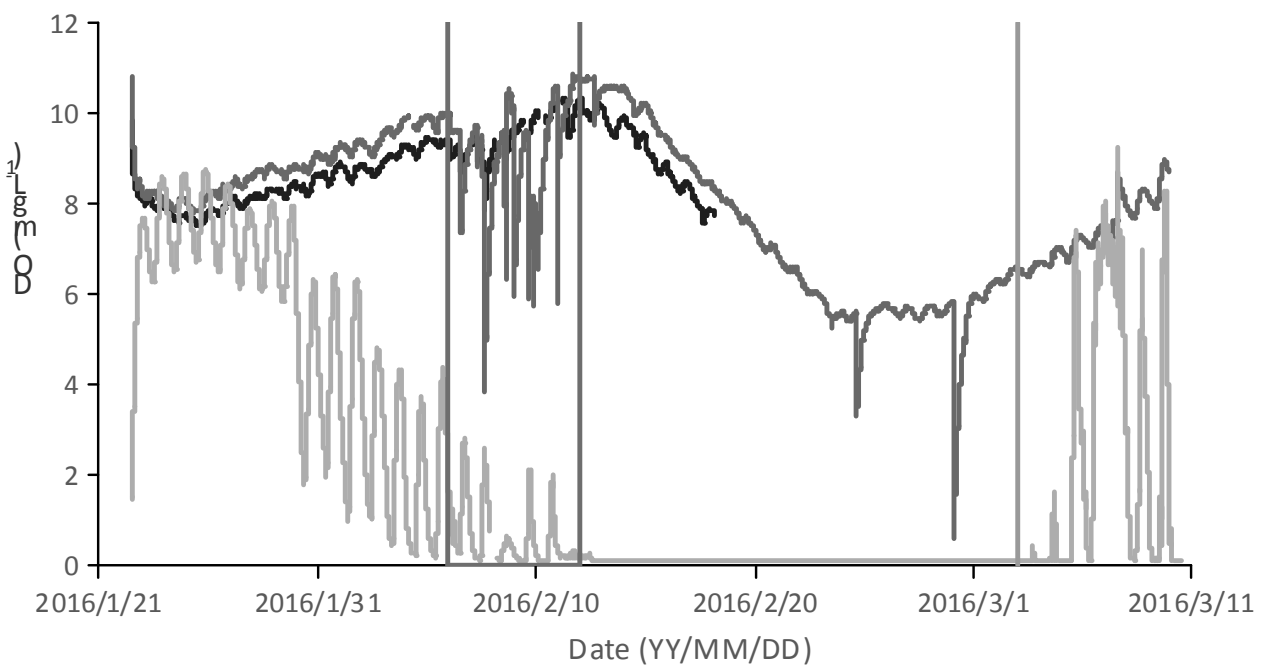

Fig. 2 


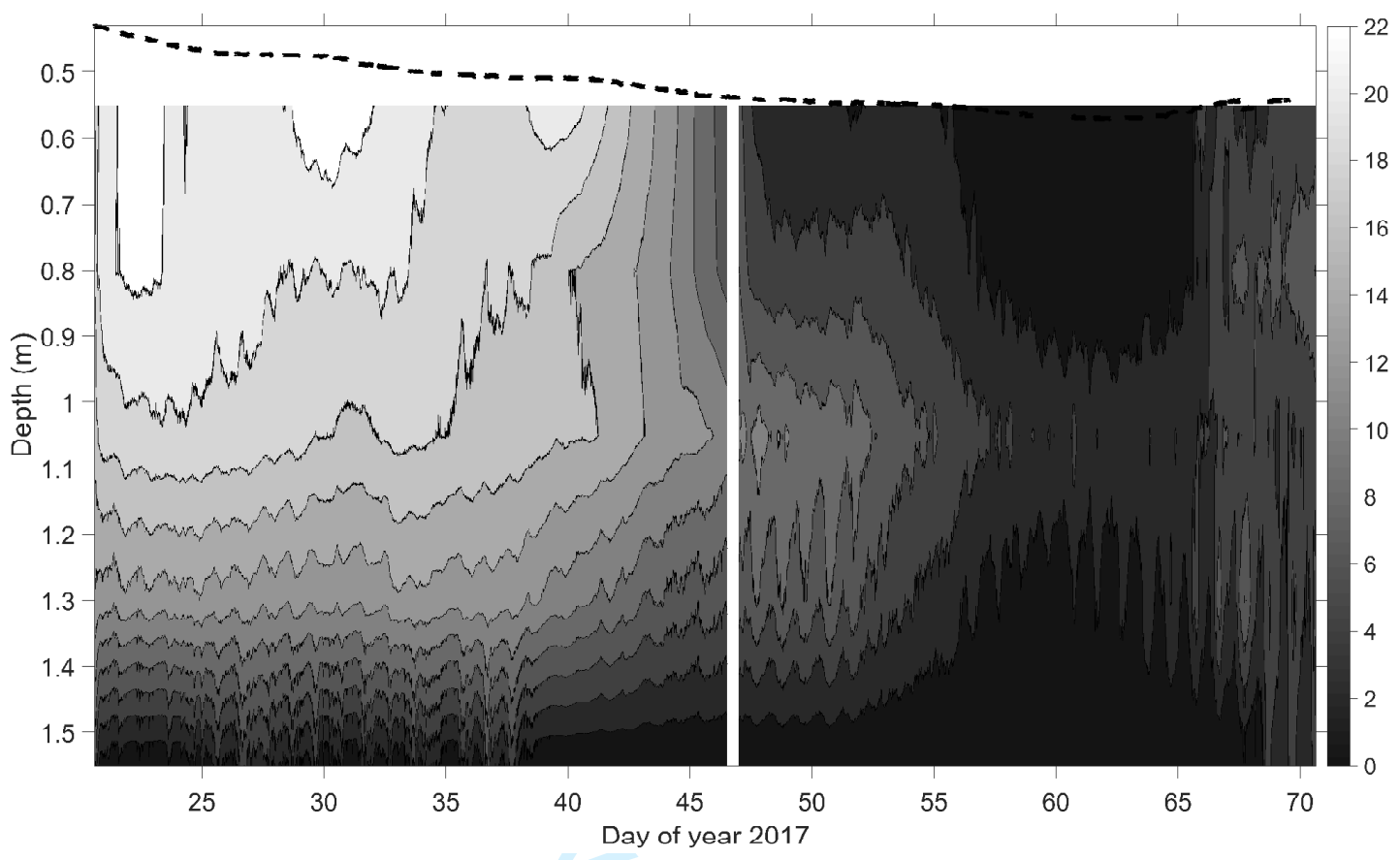

Fig. 3

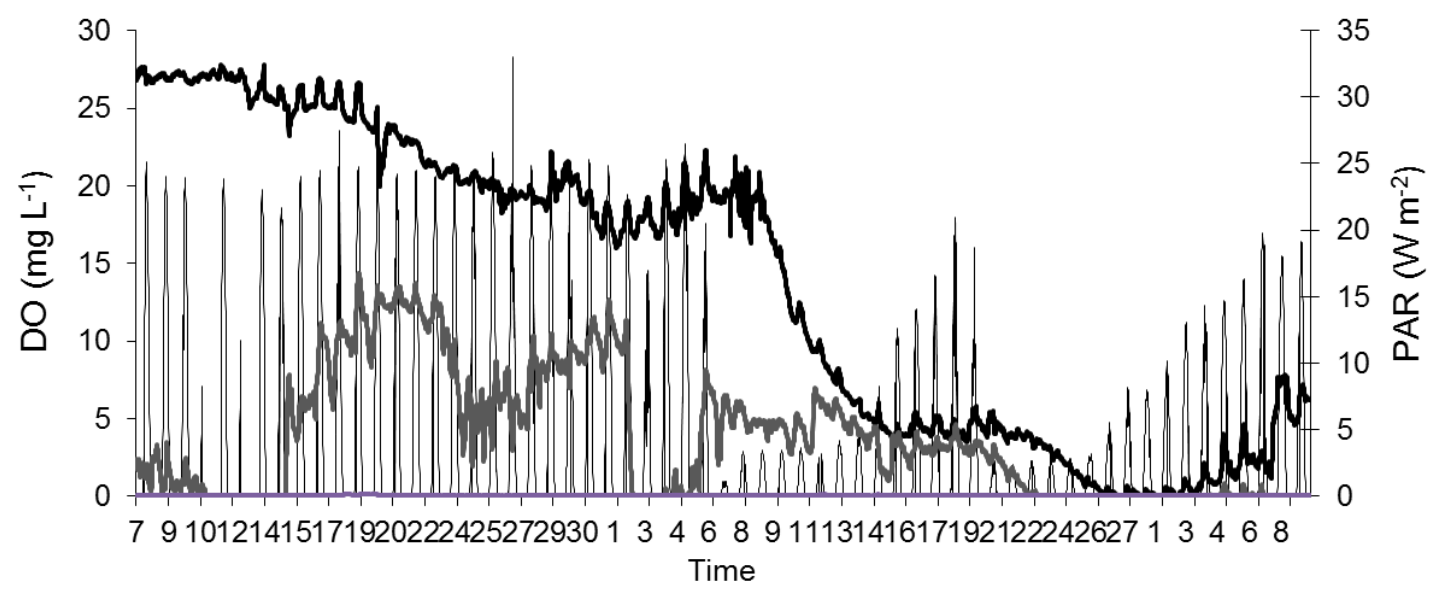

Fig. 4 

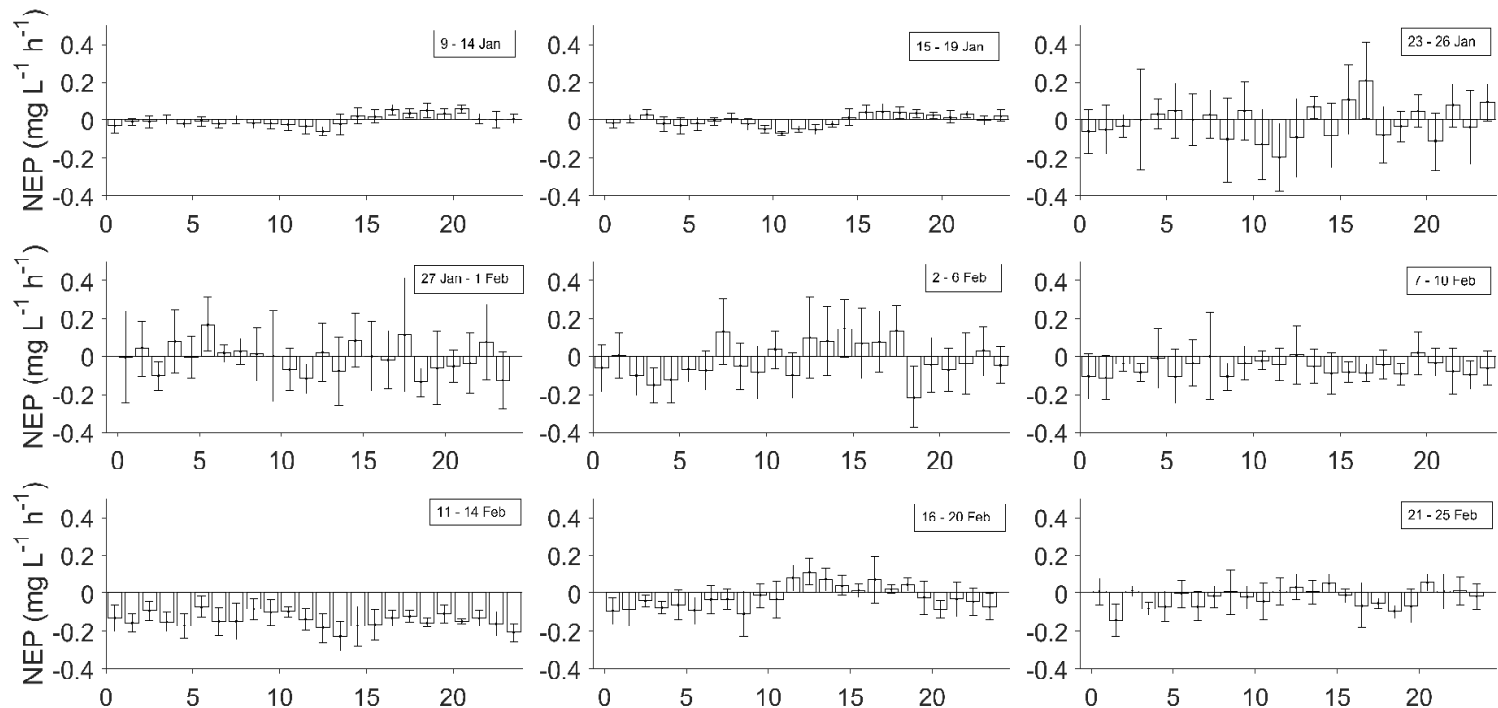

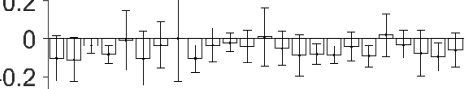
$\begin{array}{rrrrr}0.4 & 5 & 10 & 15 & 20\end{array}$

0.4 ב 0.4 Feb-2 Mar

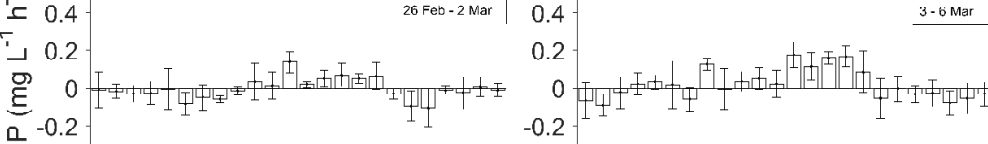

岸 -0.4

$\begin{array}{llll}5 & 10 & 15 & 20 \\ \text { Time of day (hour) }\end{array}$

$-0.4$

$\begin{array}{lll}5 & 10 & 15 \\ \text { Time of day (hour) } & 20\end{array}$
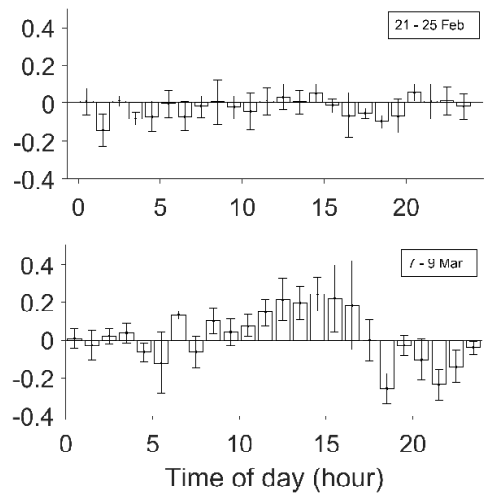

Fig. 5

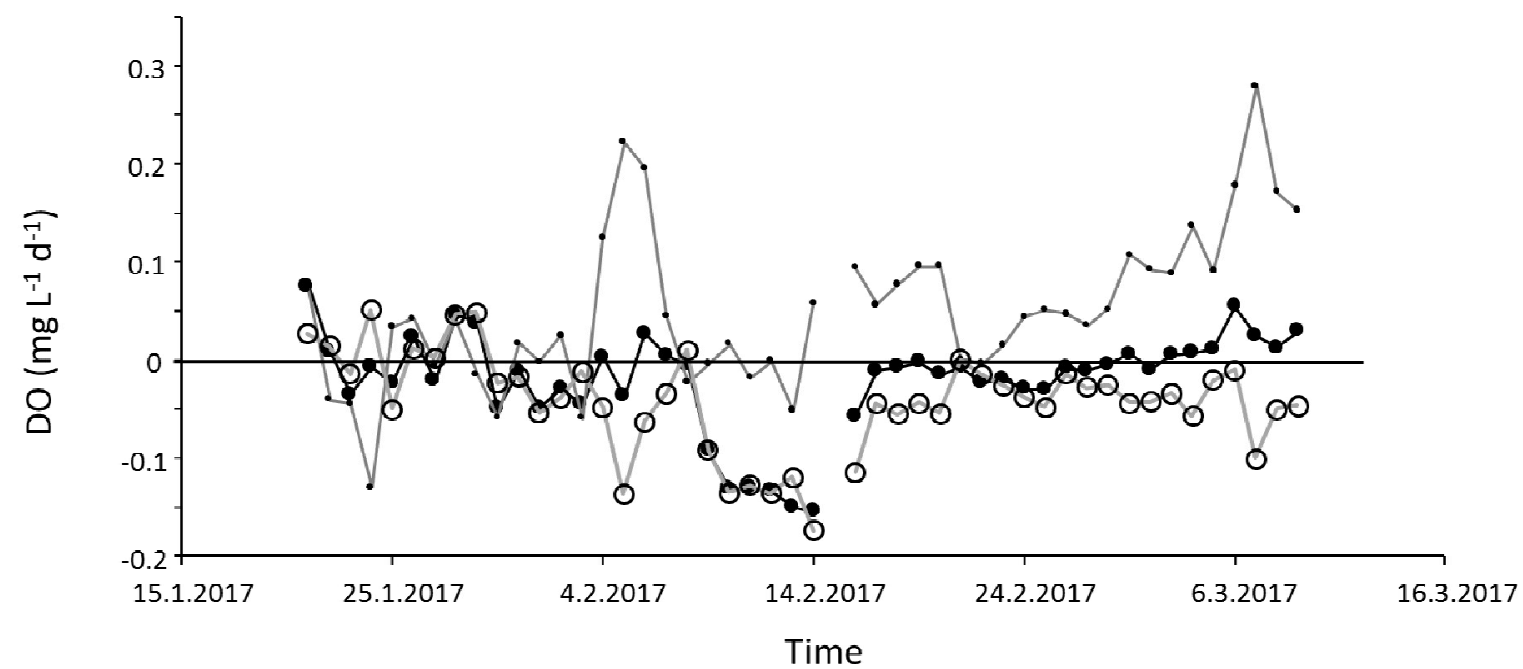

Fig. 6 


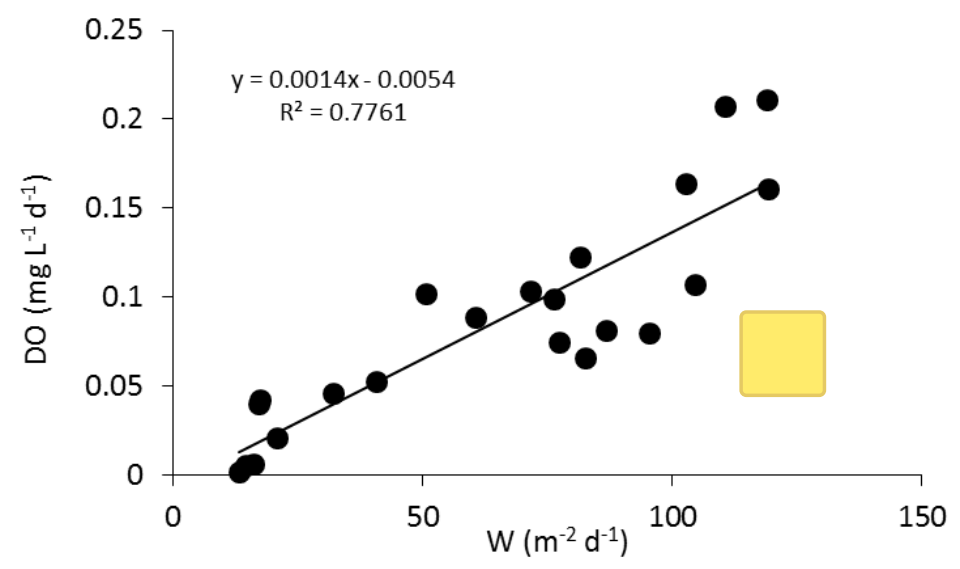

Fig. 7

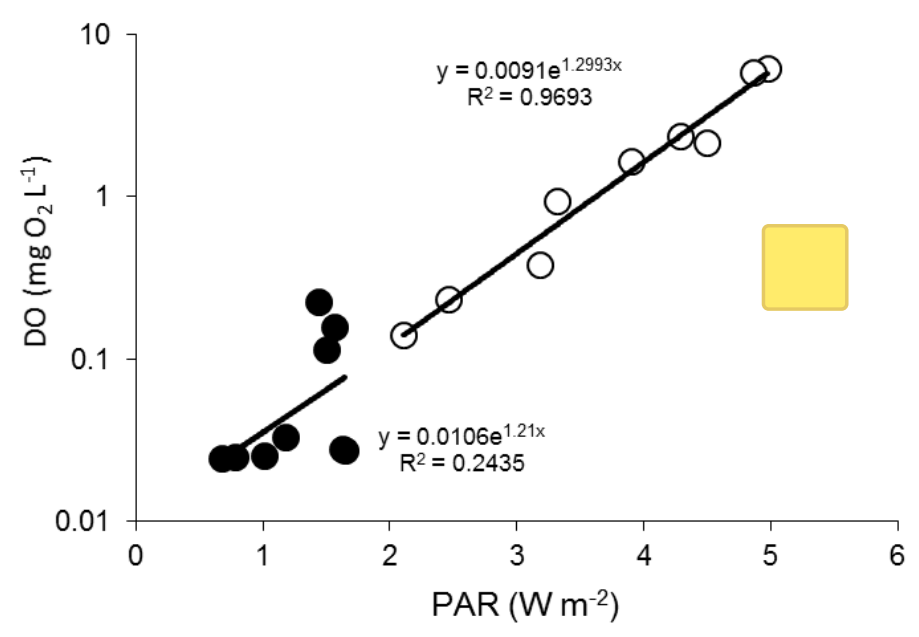

Fig. 8 
Page 21 of 25

Freshwater Biology

$$
\begin{aligned}
& 1 \\
& 2 \\
& 3 \\
& 4 \\
& 5 \\
& 6 \\
& 7 \\
& 8 \\
& 9 \\
& 10 \\
& 11 \\
& 12 \\
& 13 \\
& 14 \\
& 15 \\
& 16 \\
& 17 \\
& 18 \\
& 19 \\
& 20 \\
& 21 \\
& 22 \\
& 23 \\
& 24 \\
& 25 \\
& 26 \\
& 27 \\
& 28 \\
& 29 \\
& 30 \\
& 31 \\
& 32 \\
& 33 \\
& 34 \\
& 35 \\
& 36 \\
& 37 \\
& 38 \\
& 39 \\
& 40 \\
& 41 \\
& 42 \\
& 43 \\
& 44 \\
& 45 \\
& 46 \\
& 47 \\
& 48 \\
& 49 \\
& 50 \\
& 51 \\
& 52 \\
& 53 \\
& 54 \\
& 55 \\
& 56 \\
& 57 \\
& 58 \\
& 59 \\
& 60
\end{aligned}
$$

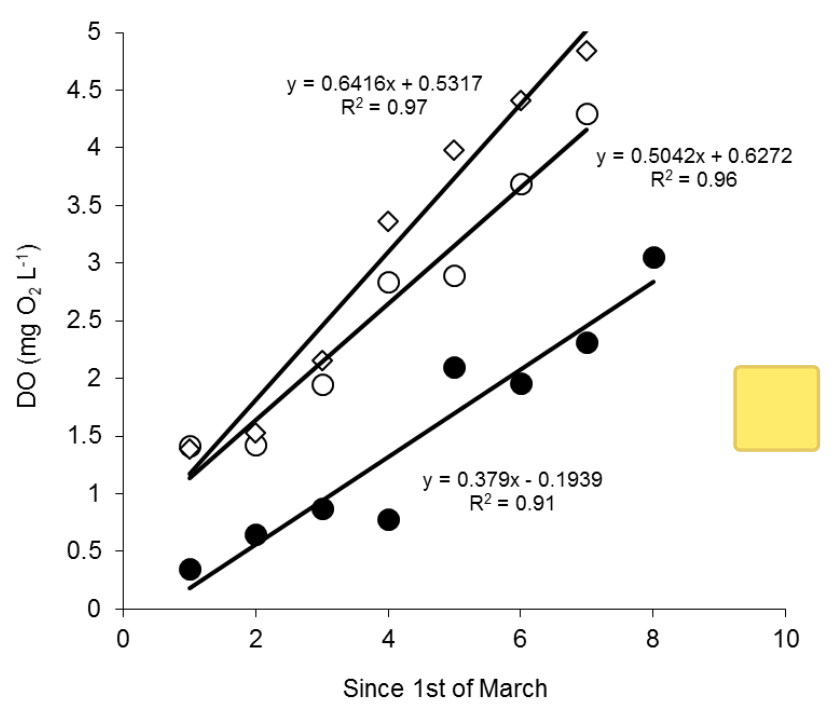

Fig. 9 
Supplementary data

S1 The methods/devices used for chemical analyses.

\begin{tabular}{|c|c|c|c|c|}
\hline & equipments & chemicals & standards & methods \\
\hline $\mathrm{TN}$ & $\begin{array}{l}\text { Ultraviolet } \\
\text { spectrophotometer(UH5300), } \\
\text { Digestion device } \\
\text { (HACH DRB200) }\end{array}$ & $\mathrm{K}_{2} \mathrm{~S}_{2} \mathrm{O}_{8}, \mathrm{NaOH}, \mathrm{HCl}$ & GB11894-89 & $\begin{array}{l}\text { Alkaline potassium } \\
\text { persulphate } \\
\text { digestion-UV } \\
\text { spectrophotometric } \\
\text { method }\end{array}$ \\
\hline $\mathrm{NH}_{3}-\mathrm{N}$ & $\begin{array}{l}\text { Ultraviolet } \\
\text { spectrophotometer(UH5300), } \\
\text { electric furnace }\end{array}$ & $\begin{array}{l}\mathrm{NaOH}, \mathrm{KI}, \mathrm{HgI}, \\
\mathrm{C}_{4} \mathrm{H}_{4} \mathrm{O}_{6} \mathrm{KNa} \cdot 4 \mathrm{H}_{2} \mathrm{O}\end{array}$ & HJ535-2009 & $\begin{array}{l}\text { Water } \\
\text { Determination } \\
\text { Of ammonia } \\
\text { nitrogen-Nessler's reagent } \\
\text { spectrophotometry }\end{array}$ \\
\hline TP & $\begin{array}{l}\text { Ultraviolet } \\
\text { spectrophotometer(UH5300), } \\
\text { Digestion devic } \\
\text { (HACH DRB200) }\end{array}$ & $\begin{array}{l}\mathrm{H}_{2} \mathrm{SO}_{4} \mathrm{C}_{6} \mathrm{H}_{8} \mathrm{O}_{6}, \\
\left(\mathrm{NH}_{4}\right)_{6} \mathrm{MO}_{7} \mathrm{O}_{4} \cdot 4 \mathrm{H}_{2} \mathrm{O}, \\
\mathrm{K}(\mathrm{SbO}) \mathrm{C}_{4} \mathrm{H}_{4} \mathrm{O}_{6} \cdot 1 / 2 \mathrm{H}_{2} \mathrm{O}, \\
\mathrm{K}_{2} \mathrm{~S}_{2} \mathrm{O}_{8}\end{array}$ & GB11893-89 & $\begin{array}{l}\text { Ammonium } \\
\text { molybdate } \\
\text { spectrophotometry }\end{array}$ \\
\hline Chl-a & $\begin{array}{l}\text { Centrifuge,Solvent filter, } \\
\text { Filter membrane, } \\
\text { Refrigerato,Glass cuvette }\end{array}$ & $\mathrm{CH}_{3} \mathrm{COCH}_{3}$ & SL88-2012 & $\begin{array}{l}\text { Water quality- } \\
\text { Determination } \\
\text { of chlorophyll } \\
\text { by spectrophotometry }\end{array}$ \\
\hline Turbidity & $\begin{array}{l}\text { 2100N } \\
\text { TURBIDIMETER (HACH) }\end{array}$ & & & \\
\hline $\begin{array}{c}\mathrm{EC} \\
\mathrm{pH} \\
\mathrm{TDS}\end{array}$ & $\begin{array}{l}\text { Portable multi } \\
\text { parameter water quality } \\
\text { testing instrument } \\
\text { (YSI ProPlus) }\end{array}$ & & & \\
\hline
\end{tabular}


S2 Water temperature in winter 2015-2016 (A), and temperature profile in 2016-2017 drawn with lines showing isotherms at 1 degree intervals over the study period since December 26 until March 13 (B). light grey line indicates in A) results of the topmost sensor $(0.70 \mathrm{~m})$, dark grey of the middle sensor $(1.06 \mathrm{~m})$ and black of the lowest sensor (2.06 m). Depth of the site was $2.20 \mathrm{~m}$. In B) black broken line denotes ice thickness, i.e. the lower surface of the ice cover.

A.

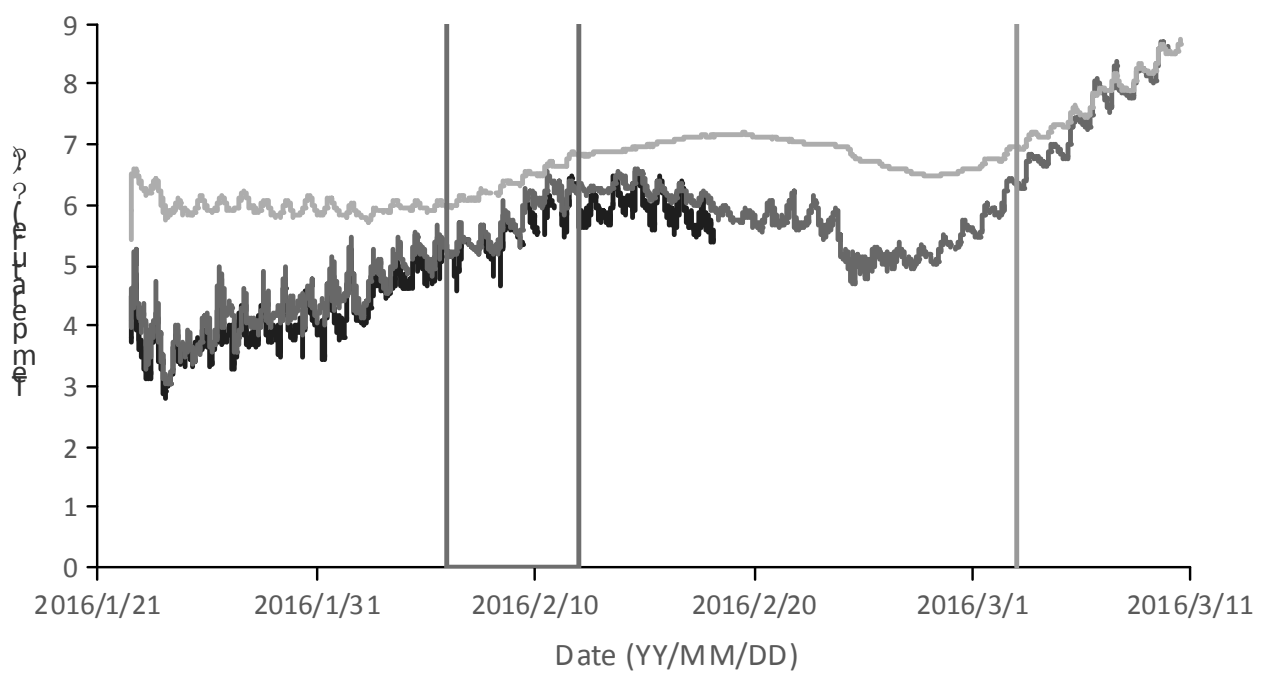

B.

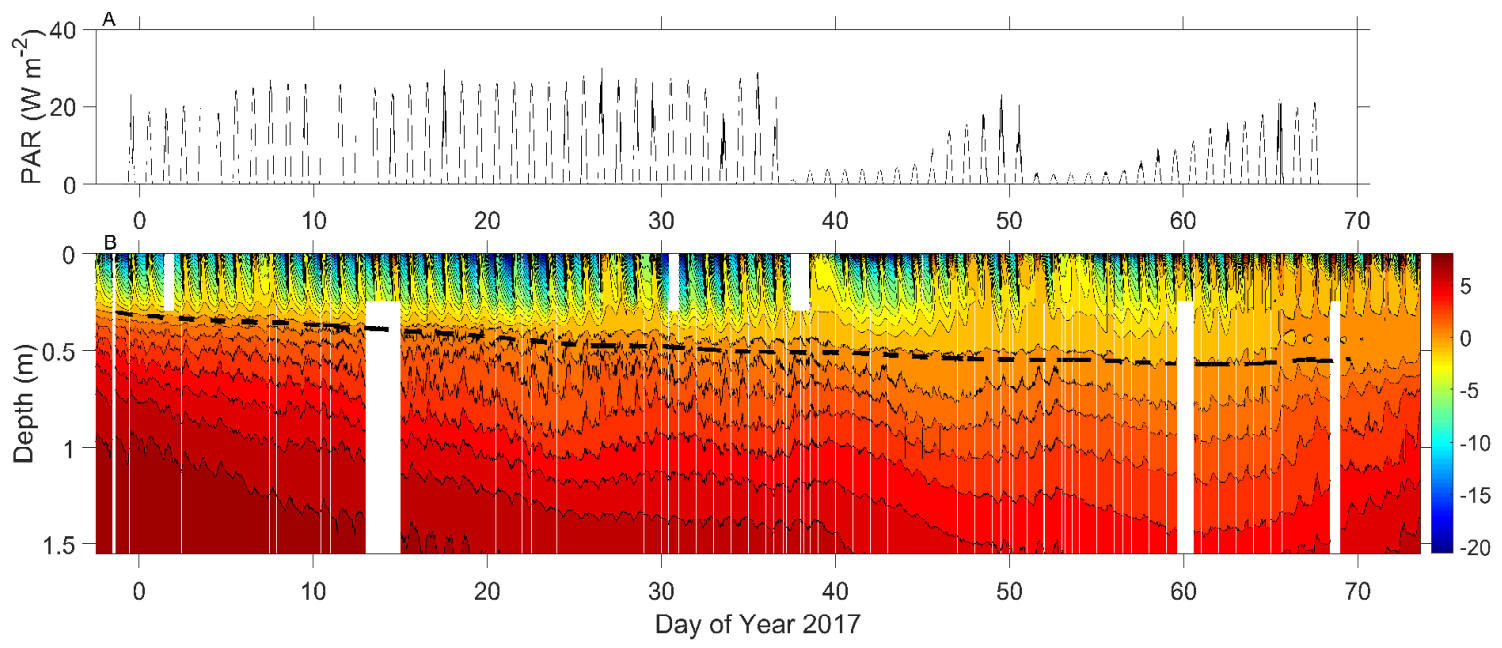


S3 Summary of chemical results of water column in winter 2016-2017. Lab represents the data from laboratory determinations, Station represents the data from sensor measurements in the field.

\begin{tabular}{|c|c|c|c|c|c|c|c|c|c|}
\hline & & $\begin{array}{l}\text { TDS } \\
\text { ppt }\end{array}$ & $\begin{array}{c}\mathrm{EC} \\
\mathrm{mS} \mathrm{m}{ }^{-1}\end{array}$ & $\begin{array}{l}\text { Turb } \\
\text { NTU }\end{array}$ & $\begin{array}{c}\mathrm{TP} \\
\mathrm{mg} \mathrm{L} \mathrm{L}^{-1}\end{array}$ & $\begin{array}{c}\mathrm{TN} \\
\mathrm{mg} \mathrm{L}^{-1}\end{array}$ & $\begin{array}{l}\mathrm{NH} 4-\mathrm{N} \\
\mathrm{mg} \mathrm{L}^{-1}\end{array}$ & $\mathrm{pH}$ & $\begin{array}{l}\text { Chl a } \\
\mathrm{mg} \mathrm{L}^{-1}\end{array}$ \\
\hline \multirow{3}{*}{$\mathrm{Lab}$} & mean & 2.2 & 4.4 & 5.6 & 0.05 & 1.63 & 0.46 & 9.1 & 9.8 \\
\hline & median & 2.1 & 4.3 & 4.9 & 0.05 & 1.56 & 0.45 & 9.1 & 7.9 \\
\hline & range & $2.0-2.5$ & $4.0-5.1$ & $3.8-26.3$ & $0.04-0.10$ & $1.45-2.54$ & $0.39-0.64$ & $8.4-9.3$ & $5.8-18.5$ \\
\hline Station & mean & & 5.9 & & & & & 9.2 & \\
\hline
\end{tabular}

S4 Chemical stratification of lake water in winter 2016-2017 at L15A. The values are means of 8 samplings between January 5 and March 11, 2017.

\begin{tabular}{|c|c|c|c|c|c|c|c|c|}
\hline $\begin{array}{l}\text { the distance from sediment } \\
\qquad \mathrm{cm}\end{array}$ & $\begin{array}{c}\mathrm{TP} \\
\mathrm{mg} \mathrm{L}^{-1}\end{array}$ & $\begin{array}{l}\text { NH4-N } \\
\mathrm{mg} \mathrm{L}^{-1}\end{array}$ & $\begin{array}{l}\text { Chl a } \\
\mathrm{mg} \mathrm{L}^{-1}\end{array}$ & $\begin{array}{l}\text { TDS } \\
\text { ppt }\end{array}$ & $\begin{array}{l}\text { Turb } \\
\text { NTU }\end{array}$ & $\mathrm{pH}$ & $\begin{array}{c}\mathrm{TN} \\
\mathrm{mg} \mathrm{L}^{-1}\end{array}$ & $\begin{array}{c}\mathrm{EC} \\
\mathrm{mS} \mathrm{m} \mathrm{m}^{-1}\end{array}$ \\
\hline 155 & 0.05 & 0.44 & 8.6 & 2.0 & 7.6 & 9.0 & 1.77 & 4.1 \\
\hline 150 & 0.06 & 0.44 & 5.8 & 2.0 & 5.5 & 9.0 & 1.82 & 4.0 \\
\hline 145 & 0.05 & 0.46 & 7.6 & 2.1 & 5.9 & 9.0 & 1.88 & 4.3 \\
\hline 140 & 0.05 & 0.39 & 6.5 & 2.1 & 5.4 & 9.1 & 1.75 & 4.3 \\
\hline 135 & 0.05 & 0.44 & 6.3 & 2.1 & 4.7 & 9.1 & 1.61 & 4.3 \\
\hline 130 & 0.05 & 0.50 & 7.6 & 2.1 & 4.3 & 9.1 & 1.58 & 4.2 \\
\hline 125 & 0.05 & 0.51 & 7.5 & 2.1 & 4.3 & 9.1 & 1.52 & 4.2 \\
\hline 120 & 0.05 & 0.42 & 7.3 & 2.1 & 3.9 & 9.1 & 1.53 & 4.2 \\
\hline 115 & 0.05 & 0.44 & 6.3 & 2.1 & 4.6 & 9.1 & 1.56 & 4.2 \\
\hline 110 & 0.04 & 0.41 & 6.8 & 2.1 & 3.8 & 9.1 & 1.59 & 4.2 \\
\hline 105 & 0.04 & 0.48 & 6.9 & 2.1 & 3.8 & 9.1 & 1.51 & 4.2 \\
\hline \multicolumn{9}{|l|}{100} \\
\hline 95 & 0.05 & 0.46 & 8.0 & 2.1 & 5.4 & 9.1 & 1.54 & 4.3 \\
\hline 90 & 0.06 & 0.42 & 8.4 & 2.1 & 6.5 & 9.1 & 1.61 & 4.3 \\
\hline 85 & 0.05 & 0.41 & 7.2 & 2.1 & 7.4 & 9.2 & 1.60 & 4.3 \\
\hline 80 & 0.04 & 0.45 & 7.5 & 2.1 & 5.7 & 9.2 & 1.64 & 4.3 \\
\hline
\end{tabular}




\begin{tabular}{lllllllll}
75 & 0.04 & 0.45 & 9.1 & 2.1 & 6.4 & 9.2 & 1.50 & 4.4 \\
70 & 0.04 & 0.48 & 7.4 & 2.1 & 4.8 & 9.2 & 1.48 & 4.4 \\
65 & 0.05 & 0.42 & 7.0 & 2.1 & 5.9 & 9.2 & 1.47 & 4.4 \\
60 & 0.05 & 0.46 & 7.8 & 2.1 & 4.8 & 9.2 & 1.51 & 4.4 \\
55 & 0.04 & 0.47 & 9.0 & 2.1 & 6.2 & 9.2 & 1.48 & 4.4 \\
50 & 0.05 & 0.43 & 7.9 & 2.1 & 5.3 & 9.2 & 1.47 & 4.3 \\
45 & 0.04 & 0.39 & 8.0 & 2.1 & 4.9 & 9.2 & 1.48 & 4.3 \\
40 & 0.05 & 0.42 & 10.5 & 2.2 & 4.9 & 9.2 & 1.51 & 4.4 \\
35 & 0.06 & 0.41 & 10.0 & 2.2 & 4.6 & 9.1 & 1.54 & 4.5 \\
30 & 0.05 & 0.49 & 11.1 & 2.2 & 4.2 & 9.1 & 1.51 & 4.5 \\
25 & 0.05 & 0.43 & 13.2 & 2.2 & 4.2 & 9.1 & 1.45 & 4.5 \\
20 & 0.06 & 0.49 & 12.5 & 2.2 & 4.2 & 9.1 & 1.69 & 4.6 \\
15 & 0.07 & 0.49 & 16.1 & 2.3 & 4.6 & 9.0 & 1.59 & 4.7 \\
10 & 0.10 & 0.64 & 13.0 & 2.4 & 7.9 & 8.8 & 1.92 & 4.9 \\
5 & 0.10 & 0.58 & 18.5 & 2.5 & 26.3 & 8.4 & 2.54 & 5.1 \\
\hline
\end{tabular}

